\title{
LC50 determination and intoxication symptoms of a new pyridine carboxamide pesticide Flonicamid on common carp Cyprinus carpio
}

\author{
Melika Ghelichpour*1,2, Ali T. Mirghaed ${ }^{1,2}$, Amalia P. Jimenez ${ }^{3,4}$ \\ ${ }^{1}$ University of Tehran, Tehran, Iran \\ ${ }^{2}$ Center for International Scientific Studies \& Collaboration (CISSC), Tehran, Iran \\ ${ }^{3}$ University of Granada, Granada, Spain \\ ${ }^{4}$ University of Porto, Porto, Portugal \\ *Corresponding author: m.ghelichpour@ut.ac.ir
}

\begin{abstract}
The present study was undertaken to evaluate the lethal toxicity and stress signs of Flonicamid toward juvenile common carp (Cyprinus carpio). The $96 \mathrm{~h}$ LC50 values, determined $43.17 \mathrm{mgL}^{-1}$ by probit analysis in a semi-static system. LC50 24, 48 and $72 \mathrm{~h}$ were $47.54,41.83$ and $43.51 \mathrm{mgL}^{-1}$, respectively. Behavioral changes include hyperexcitement, erratic swimming, dark coloration, loss of equilibrium and lethargy were observed with different intensities. Consequently, mortality rate, stress signs and behavioral changes observed in response to the Flonicamid are dependent to dose and time exposure.
\end{abstract}

Key words: Flonicamid, lethal concentration, Cyprinus carpio, intoxication symptoms, behavior

\section{ACKNOWLEDGMENTS}

This work has been supported the Center for International Scientific Studies \& Collaboration (CISSC), Ministry of Science Research Technology.

\section{Article history:}

Received: 1 July 2019. Accepted: 1 August 2019

\section{For citation:}

Ghelichpour M, Mirghaed AT, Jimenez AP. LC50 Determination and intoxication symptoms of a new pyridine carboxamide pesticide Flonicamid on common carp Cyprinus carpio. RUDN Journal of Agronomy and Animal Industries, 2019; 14(3):279—288. doi: 10.22363/2312-797X-2019-14-3-279-288

\section{Introduction}

Flonicamid is the approved common name for the chemical composition, IKI220; $\mathrm{N}$-cyanomethyl-4-trifluoromethyl nicotinamide. It is a novel systemic pyridine carboxamide pesticide discovered by Ishihara Sangyo Kaisha, Ltd (Tokyo, Japan). It is used for

(C) Ghelichpour M., Mirghaed A.T., Jimenez A.P., 2019.

(c) (i) This work is licensed under a Creative Commons Attribution 4.0 International License https://creativecommons.org/licenses/by/4.0/1 
controlling hemipterous pests, and thysanopterous pests that are resistant to other insecticides. It is a useful pesticide for the control of sucking pests such as aphids, whiteflies, trips, some micro lepidoptera, and a number of coleopteran species [1]. Flonicamid causes starvation in sucking insects via inhibit their feeding. The mechanism is stop feeding by blocking the ion channel. After spraying Flonicamid, although insects are able to attach to the plant, their salivation and sap feeding are limited or completely blocked [2].

The high rate of human population growth and the rapid pace of industrialization have caused the problem of sewage disposal. The domestic wastes and untreated or partially treated industrial sewages, may have pollutants like heavy metals, pesticides and many organic compounds, affect the fish and other aquatic organisms with several negative side effect on non-target organisms such as fish disease or death. Actually, it is a well-known fact that indiscriminate use of pesticides in agriculture has resulted in extensive distribution in the environment and also has a direct impact on non-target organisms [3].

Investigation the behavior is considered as a promising tool in ecotoxicology [4]. Behavior of toxicant exposed fish is the integrative measures of neurotoxicity and reflecting biochemical and physiological reactions to the toxicant. Also, behavior is a unified result of endogenous and exogenous processes and low level of exposures have been involved in various behavioral and physiological impairments [5]. Monitoring fish behavior which exposed to pesticides performed in several investigations [4, 6].

Using pesticides is common in the extensive agriculture farms of southern region of the Caspian Sea in Iran which located nearby the fish farms. Therefore, the fish in this region, either in the sea or fish farms are endangered by pesticides [4]. As Flonicamid has a favorable toxicological profile, with low toxicity to mammals, recently, it has been widely used as a safe insecticide in the agricultural farms of this region.

The present study has aimed to determine the lethal toxicity of Flonicamid and its effects on some behavioral changes of juvenile common carp (Cyprinus carpio). Common carp is a highly edible fish and preferred for culture due to its high growth rate and prolific breeding in confined water. Also, it is commercial and an important aquaculture fish species in the southern Caspian Sea. Common carp is cultured for food consumption and also restoration of fish stocks.

\section{Materials and methods}

\section{Fish maintenance \& pesticide preparation}

Total number of 200 juvenile common carp with average weight and length of $48 \pm 4.25 \mathrm{~g}$ and $11 \pm 1.5 \mathrm{~cm}$, respectively, were stored in a $2000 \mathrm{~L}$ capacity fiberglass tank. During two weeks acclimation, the fish were fed $1.5 \%$ of the body weight with commercial carp feed, twice a day (Mazandaran Animal \& Aquatic Feed Co., Sari, Mazandaran, Iran) and aerated continuously. 50 \% water exchanging performed daily. Leftover food in the tank was removed daily when water of the tank was changed. Physicochemical properties of water were monitored during the experiment. Water temperature, dissolved oxygen, salinity, and $\mathrm{pH}$ were measured by Hach HQ40d 
portable apparatus (Loveland, Colorado, USA). Also, photometer (Wagtech 7100, Berkshire, UK) was used to calculate total hardness, alkalinity, and calcium.

\section{Behavior monitoring}

The fish behaviors, clinical and apparent characteristics were monitored during Flonicamid exposure daily. Changes in fish swimming and coloration and any other apparent symptoms were reported for each group to compare the effect of concentration and time of Flonicamid exposure on experimental fish.

\section{Determination of lethal concentration}

150 common carp were distributed into 15 fiberglass tanks with $160 \mathrm{~L}$ volume. The tanks were considered as five groups for five different Flonicamid concentrations. Three replicate were taken for each concentration. 0 (control), 30, 40, 50 and $60 \mathrm{mg} \mathrm{L}^{-1}$ were determined according to the pre range finding test. The fish were exposed to the distinct concentrations of Flonicamid (with specifications in Table 1) for $96 \mathrm{~h}$ to determine LC50 values after 24, 48, 72 and $96 \mathrm{~h}$. They were starved $24 \mathrm{~h}$ prior to exposing and during assay no food was given to the fish. The mortality was recorded in each group and dead fish were removed from tanks. Simultaneously renewed water, some amount of the pesticide were added into tanks to keep the concentration of the treatments, daily.

Table 1

Specifications of Flonicamid

\begin{tabular}{|c|c|c|c|c|c|}
\hline Pesticide & CAS number & Supplier & Grade & Chemical name & $\begin{array}{l}\text { Alternative } \\
\text { name }\end{array}$ \\
\hline Flonicamid & $158062-67-0$ & $\begin{array}{c}\text { Ishiharab } \\
\text { Sangyo Kaisha, } \\
\text { Ltd Tokyo, } \\
\text { Japan }\end{array}$ & $\begin{array}{c}\text { Commercial } \\
\text { formulation } \\
(50 \% \text { WG })\end{array}$ & $\begin{array}{c}\mathrm{IKI} 220 ; \\
\text { N-cyanomethyl- } \\
\text { 4-trifluoromethyl } \\
\text { nicotinamide }\end{array}$ & Teppeki \\
\hline
\end{tabular}

\section{Analysis}

The fish behavior was monitored immediately after exposure to Flonicamid and continued every one hour in the first day. Then, the fish behavior was investigated three times a day in every $24 \mathrm{~h}$ up to $96 \mathrm{~h}$ after Flonicamid exposure. Data on mortality of fish were investigated according to time by probit method in statistical SPSS software (version 17). Based on probit analysis method, LC50 values and 95 \% lower and upper confidence limits determined. In Finney's method, a regression equation and graphical interpolation are used to determine the LC50 value. To draw the graphical interpolation, logarithms of the chemical compound concentration and the probit value of percentage mortality are used on the $X$ axis and $Y$ axis, respectively. The $95 \%$ confidence limits of the LC50 values were calculated by the formula of Mohapatra, Rengarajan [7] in Finney’s method.

\section{Results and discussion}

Physicochemical characteristics of water in the experiment were checked daily to establish the environmental parameters. Table 2 shows these parameters. 
Physicochemical characteristics of water

\begin{tabular}{l|c|c}
\hline \multicolumn{1}{c|}{ Characteristics } & Unit & Mean \pm SD \\
\hline Water temperature & ${ }^{\circ} \mathrm{C}$ & $27.5 \pm 1.25$ \\
\hline $\mathrm{pH}$ & - & $8.5 \pm 0.25$ \\
\hline Dissolved oxygen & $\mathrm{mg} \mathrm{L}^{-1}$ & $7.1 \pm 0.84$ \\
\hline Salinity & $\mathrm{mg} \mathrm{L}^{-1}$ & $2.63 \pm 0.15$ \\
\hline Electro conductivity & $\mu \mathrm{m} \mathrm{cm}^{-1}$ & $4630 \pm 55$ \\
\hline Total hardness (as CaCO3) & $\mathrm{mg} \mathrm{L}^{-1}$ & $300 \pm 17.5$ \\
\hline Alkalinity (as CaCO3) & $\mathrm{mg} \mathrm{L}^{-1}$ & $350 \pm 20.3$ \\
\hline Calcium & $\mathrm{mg} \mathrm{L}^{-1}$ & $110 \pm 11.7$
\end{tabular}

\section{Toxicity stress and behavioral and apparent physiological symptoms}

Uncoordinated behavior was observed in fish exposed to different concentrations of Flonicamid. At the initial of exposure, the brownish gray powder of Flonicamid caused the water appearance foamy and cloudy. The fish stopped swimming with a swinging motion in their location in response to sudden changes in the surrounding environment. Then, to avoid the toxicant water, they swam to the water surface with hyper excitement behavior and fast swimming which seems this behavior was because of low oxygen conditions. Also, faster activity of opercula was observed as surfacing and gulping of air. After some time, the fish became slow with erratic swimming. Body pigmentation increased, therefore, the fish coloration became dark especially fins and tail. The darkish color increased gradually and expanded to other parts of the body. The fish exposed to higher concentration of Flonicamid showed a faster color exchange. Eventually, fish with lateral swimming lost their equilibrium and consciousness. Then, they stayed motionless on the bottom of tank and became exhausted and lethargic. Lastly, they died with open mouth and operculum. These alterations occurred so fast in fish exposed to higher Flonicamid concentration (50 and $60 \mathrm{mgL}^{-1}$ ) compared to the lower one (30 and $40 \mathrm{mgL}^{-1}$ ) which some behaviors were not obvious clearly in higher dose, such as erratic and slow swimming.

\section{Lethal concentration of Flonicamid}

Lethal concentration (LC50) is basically for acute toxicity. LC50 is the concentration of a toxicant chemical compound such as pesticide, which kills $50 \%$ of the experimental organism in a specific period of time exposure, usually $96 \mathrm{~h}$. According to Figure 1, by increasing the concentration of Flonicamid, the fish mortality rate has also increased, which indicates a direct relationship between mortality and concentration of the pesticide. LC50 of Flonicamid after 24, 48, 72 and $96 \mathrm{~h}$ exposure were determined 47.54, 41.83, 43.51 and $43.17 \mathrm{mgL}^{-1}$, respectively (Table 3). LC10-99 in each time exposure of Flonicamid is in Table 4. 


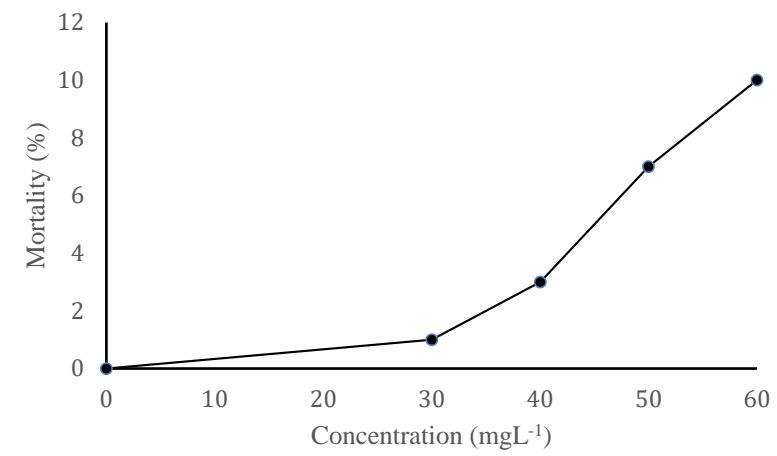

Fig. 1. Percentage mortality of Cyprinus carpio after $96 \mathrm{~h}$ exposure to different concentrations of Flonicamid

Lethal concentration of Flonicamid $\left(\mathrm{mgL}^{-1}\right)$

Table 3

\begin{tabular}{c|c|c|c|c|c|c}
\hline \multirow{2}{*}{ Duration $(\mathrm{h})$} & $\begin{array}{c}\text { LC50 values } \\
\left(\mathrm{mg} \mathrm{L}^{-1}\right)\end{array}$ & \multicolumn{2}{|c|}{$95 \%$ confidence limit } & \multirow{2}{*}{ Slope \pm SE } & Intercept \pm SE & \multirow{2}{*}{ Sig } \\
\cline { 3 - 4 } & 47.54 & lower & upper & & \\
\hline 24 & 41.83 & 35.05 & 48.18 & $14.48 \pm 4.38$ & $-23.49 \pm 7.18$ & 0.001 \\
\hline 48 & 43.51 & 38.88 & 48.09 & $28.37 \pm 8.63$ & $-46.49 \pm 14.20$ & 0.001 \\
\hline 72 & 43.17 & 37.36 & 48.77 & $18.29 \pm 5.36$ & $-29.91 \pm 8.83$ & 0.001
\end{tabular}

Lethal concentrations of Flonicamid (mgL-1) (95\% confidence intervals)

Table 4 depending on exposure time for Cyprinus carpio

\begin{tabular}{c|c|c|c|c}
\hline \multirow{2}{*}{$\begin{array}{c}\text { Lethal } \\
\text { concentration }\end{array}$} & 24 & 48 & 72 & 96 \\
\cline { 2 - 5 } & 38.99 & 29.50 & 36.40 & 32.74 \\
& $(27.68-43.38)$ & $(16.34-35.16)$ & $(26.71-40.24)$ & $(21.17-31.70)$ \\
\hline LC10 & 47.54 & 41.83 & 43.51 & 43.17 \\
& $(42.35-52.67)$ & $(35.05-48.18)$ & $(38.88-48.09)$ & $(37.36-48.77)$ \\
\hline LC90 & 57.97 & 59.32 & 52 & 56.92 \\
& $(52.40-79.09)$ & $(50.69-97.89)$ & $(47.28-68.80)$ & $(50.01-83.17)$ \\
\hline LC99 & 71.98 & 86.85 & 63.18 & 76.97 \\
& $(60.94-133.71)$ & $(65.73-244.75)$ & $(54.30-109.63)$ & $(61.73-165.86)$
\end{tabular}

Some apparent physiological and behavioral alterations observed in juvenile common carp exposed to Flonicamid and they were obvious approximately $30 \mathrm{~min}$ after exposure to the highest concentration of Flonicamid $\left(60 \mathrm{mgL}^{-1}\right)$. The sequence of intoxication symptoms were initially stopped swimming with a swinging motion due to abrupt stress (it was clear in high Flonicamid concentrations), hyperactivity and irregular swimming, swimming near the water surface for oxygen uptake, erratic swimming, darkening the body color due to accumulation of pigments, lethargy because of energy consumption to against stress and death, ultimately. Some behavior alterations and intoxication symptoms observed in the previous studies. Jonsson, Toledo [8] reported excitation, erratic swimming with increase in respiratory frequency, swimming near the water surface for oxygen uptake, convulsion and hysteria in two species Hyphessobrycon bifasciatus and Brachydanio rerio exposed to acute toxicity of endosulfan. Joshi, Rege [9] also noticed similar symptoms in Gambusiaaffinis exposed to other organochlorine insecticides such as DDT and BHC and a few inorganic salts. The teleosts exposed to pyrethroids and some organophosphates showed behavior alterations and intoxication symptoms [10]. 
Hyperactivity and irregular movement are the symptoms related to the central nervous symptoms. Although the mecanism of action of Flonicamid is not comletely known in fish, this pesticide may interfere withthe connection of some neurotransmitters in specific receptors like their function in insects [8]. Alterations in the levels of intra- and extracellular sodium and potassium may be another reason to the hyperactivity and irregular movement in fish exposed to the pesticides [11]. The various behavioral changes such as abnormal swimming, jerks of body, loss of balance and anorexia are some indications observed in Oreochromis niloticus and Chrysichthys auratus exposed to atrazine, Channa punctatus exposed to mecuric chloride and malathion and Heteropneutes fossilis exposed to Malathion [12-14]. Fast swimming and jumping, faster opercula activity, erratic swimming, vigorous jerks of the body, mucus elevation, increased body pigmentation, loss of balance and consciousness, rolling movement, became exhausted and lethargic were the intoxication symptoms reported in Channa punctatus exposed to carbosulfan, glyphosate and atrazine [6].

Dark coloration due to pesticides exposure is a symptom which reported in previous studies like Cyprinus carpio exposet to indoxacarb, Salmo salar and Oncorhynchus mykiss exposed to emamectin benzoate [15, 16]. Dark coloration of fish exposed to Flonicamid might be as a result of interference of pesticide in melanophore aggregation due to cortisol hormone elevation in the stressful condition. According to Nunes, Gaio, Carvalho, Guilhermino [17] different factors may affect dark pigmentation in fish for example, capture, environmental stress, and as a defense mechanism when they feel threatened. Increasing the intensity of fish pigmentation associates with stress responsiveness, since fish subjected to stressful conditions [18]. Common carp to 2,4-Dichlorophenoxyacetic acid [19] showed light coloration. Light coloration may due to mucus hypersecretion.

Acute toxicity data has been used to determine water quality guidelines. The results of the LC50 (median lethal concentration) of the present study at $96 \mathrm{~h}$ were $43.17 \mathrm{mgL}^{-1}$ for Flonicamid. Therefore, it seems Flonicamid may be the moderate toxic substance for juvenile common carp. Toxicity of the pesticides was both time and concentration dependent, thus accounting for differences in LC10-99 values attained at different times and concentrations of exposure. There is no report on Flonicamid LC50 in any fish species. Therefore, may be further investigations show different data even in the common carp. Because toxicity of chemicals to aquatic organisms has been shown to be affected by age, size, health of the species and also, physiological parameters like temperature, $\mathrm{pH}$, dissolved oxygen and turbidity of water and concentration and formulation of chemical [20].

\section{Conclusions}

The result of the present study showed that Flonicamid as a new pesticide has adverse effects on behavioral and some apparent physiological parameters of common carp. Initially swinging motion, hyperexcitement, erratic swimming, dark coloration, loss of equilibrium and lethargy are the intoxication symptoms due to Flonicamid exposure. The symptoms are related to the time and concentration of Flonicamid exposure as other pesticides. Calculating the lethal concentration of Flonicamid in different times and concentrations indicate that pesticide toxicity depends on different parameters. 


\section{References}

1. Cho SR, Koo HN, Yoon C, Kim GH. Sublethal effects of Flonicamid and thiamethoxam on green peach aphid, Myzus persicae and feeding behavior analysis. Journal of the Korean Society for Applied Biological Chemistry. 2011; 54(6):889—898. doi: 10.1007/BF03253177

2. Morita M, Ueda T, Yoneda T, Koyanagi T, Haga T. Flonicamid, a novel insecticide with a rapid inhibitory effect on aphid feeding. Pest Management Science: formerly Pesticide Science. 2007; 63(10):969—973. doi: 10.1002/ps.1423

3. Pazhanisamy K, Indra N. Toxic effects of arsenic on protein content in the fish, Labeo rohita (Hamilton). Nature, Environment and Pollution Technology. 2007; 6(1):113-116.

4. Mirghaed AT, Ghelichpour M. Determination of lethal concentrations of indoxacarb in fingerling Cyprinus carpio at two temperatures. International journal of aquatic biology. 2015; 3(5):339-345. doi: 10.22034/ijab.v3i5.113

5. Sandahl JF, Baldwin DH, Jenkins JJ, Scholz NL. Comparative thresholds for acetylcholinesterase inhibition and behavioral impairment in coho salmon exposed to chlorpyrifos. Environmental Toxicology and Chemistry: An International Journal. 2005; 24(1):136-145. doi: 10.1897/04-195R.1

6. Nwani CD, Nagpure NS, Kumar R, Kushwaha B, Kumar P, Lakra WS. Lethal concentration and toxicity stress of Carbosulfan, Glyphosate and Atrazine to freshwater air breathing fish Channa punctatus (Bloch). International Aquatic Research. 2010; 2:105-111.

7. Mohapatra B, Rengarajan K. Manual on bioassays in the laboratory and their techniques. CMFRI special publication. 1995; 64:1-75.

8. Jonsson CM, Toledo MCF. Acute toxicity of endosulfan to the fish Hyphessobrycon bifasciatus and Brachydanio rerio. Archives of Environmental Contamination and Toxicology. 1993; 24(2):151—155. Available from: doi: 10.1007/BF01141341

9. Joshi A, Rege M. Acute toxicity of some pesticides and a few inorganic salts to the mosquito fish Gambusia affinis (Baird \& Girard). Indian Journal of Experimental Biology. 1980; 18(4):435-437.

10. Naqvi SM, Hawkins R. Toxicity of selected insecticides (Thiodan ${ }^{\circledR}$, Security ${ }^{\circledR}$, Spartan ${ }^{\circledR}$, and Sevin ${ }^{\circledR}$ ) to mosquitofish, Gambusia alfinis. Bulletin of Environmental Contamination and Toxicology. 1988; 40(5):779—784. doi: 10.1007/BF01697530

11. Swarup PA, Rao DM, Murty A. Toxicity of endosulfan to the freshwater fish Cirrhinus mrigala. Bulletin of Environmental Contamination and Toxicology. 1981; 27(1):850-855. doi: 10.1007/BF01611106

12. Hussein S, El-Nasser M, Ahmed S. Comparative studies on the effects of herbicide atrazine on freshwater fish Oreochromis niloticus and Chrysichthyes auratus at Assiut, Egypt. Bulletin of Environmental Contamination and Toxicology. 1996; 57(3):503—510. doi: 10.1007/s001289900218

13. Pandey S, Kumar R, Sharma S, Nagpure N, Srivastava SK, Verma M. Acute toxicity bioassays of mercuric chloride and malathion on air-breathing fish Channa punctatus (Bloch). Ecotoxicology and Environmental Safety. 2005; 61(1):114-120. doi: 10.1016/ j.ecoenv.2004.08.004

14. Chandra S. Toxic effect of Malathion on acetylcholinesterase activity of liver, brain and gills of freshwater catfish Heteropneutes fossilis. Environ. Conserv. 2008; 9:45-52.

15. Taheri Mirghaed A, Ghelichpour M, Mirzargar SS, Joshaghani H, Ebrahimzadeh Mousavi H. Toxic effects of indoxacarb on gill and kidney histopathology and biochemical indicators in common carp (Cyprinus carpio). Aquaculture Research. 2018; 49(4):1616-1627. doi: 10.1111/are.13617

16. Roy W, Sutherland I, Rodger H, Varma K. Tolerance of Atlantic salmon, Salmo salar L., and rainbow trout, Oncorhynchus mykiss (Walbaum), to emamectin benzoate, a new orally administered treatment for sea lice. Aquaculture. 2000; 184(1-2):19-29. doi: 10.1016/ S0044-8486(99)00307-5

17. Nunes B, Gaio A, Carvalho F, Guilhermino L. Behaviour and biomarkers of oxidative stress in Gambusia holbrooki after acute exposure to widely used pharmaceuticals and a detergent. 
Ecotoxicology and Environmental Safety. 2008; 71(2):341-354. doi: 10.1016/ j.ecoenv.2007.12.006

18. Backström T, Brännäs E, Nilsson J, Magnhagen C. Behaviour, physiology and carotenoid pigmentation in Arctic charr Salvelinus alpinus. Journal of Fish Biology. 2014; 84(1):1—9. doi: 10.1111/jfb.12240

19. Sarikaya R, Yilmaz M. Investigation of acute toxicity and the effect of 2, 4-D (2, 4-dichlorophenoxyacetic acid) herbicide on the behavior of the common carp (Cyprinus carpio L., 1758; Pisces, Cyprinidae). Chemosphere. 2003; 52(1):195—201. doi: 10.1016/ S0045-6535(03)00106-1

20. Farah MA, Ateeq B, Ali MN, Sabir R, Ahmad W. Studies on lethal concentrations and toxicity stress of some xenobiotics on aquatic organisms. Chemosphere. 2004; 55(2):257_ 265. doi: 10.1016/j.chemosphere.2003.10.063

\begin{abstract}
About authors:
Ghelichpour Melika - Department of Aquatic Animal Health, Faculty of Veterinary Medicine, University of Tehran, 16th Azar St., Enghelab Sq., Tehran, Iran, 14174; Center for International Scientific Studies \& Collaboration (CISSC), Ministry of Science Research Technology, Tehran, Iran, 158757788; e-mail: m.ghelichpour@ut.ac.ir; SCOPUS ID: 39961248800; ORCID: 0000-0002-8338-4235

Mirghaed Ali Taheri - Department of Aquatic Animal Health, Faculty of Veterinary Medicine, University of Tehran, 16th Azar St., Enghelab Sq., Tehran, Iran, 14174; Center for International Scientific Studies \& Collaboration (CISSC), Ministry of Science Research Technology, Tehran, Iran, 15875-7788; SCOPUS ID: 56158853500

Jimenez Amalia Perez — Department of Zoology, University of Granada, Campus of Fuentenueva, Granada, Spain; Acera de San Ildefonso, Granada, Spain, 18071; Interdisciplinary Center for Marine and Environmental Research (CIIMAR), University of Porto, Porto, Portugal, 4099-002; SCOPUS ID: 7202356622
\end{abstract}

\title{
Определение средней летальной концентрации и симптомов интоксикации нового пиридинкарбоксамидного пестицида флоникамида на карпа Cyprinus carpio
}

\author{
М. Геличпур*1, 2, А.Т. Миргаед ${ }^{1,2}$, А.П. Хименес ${ }^{3,4}$ \\ ${ }^{1}$ Тегеранский университет, Тегеран, Иран \\ ${ }^{2}$ Центр международных научных исследований и сотрудничества (CISSC), \\ Тегеран, Иран \\ ${ }^{3}$ Университет Гранады, Гранада, Испания, \\ ${ }^{4}$ Университет Порту, Порту, Португалия \\ *m.ghelichpour@ut.ac.ir
}

\begin{abstract}
Аннотация. Настоящее исследование было проведено для оценки летальной токсичности и определения симптомов интоксикации флоникамида по отношению к молодому карпу (Cyprinus carpio). Средняя летальная концентрация за 96 ч отмечается при 43,17 мг/л с помощью пробит-анализа в полустатической системе. Средняя летальная концентрация через 24, 48 и 72 ч составили 47,54, 41,83
\end{abstract}


и 43,51 мг/л соответственно. Среди поведенческих изменений преобладали гипервозбуждение, неустойчивое плавание, темная окраска, потеря равновесия и летаргия, которые наблюдались с различной интенсивностью. Следовательно, уровень смертности, стрессовые признаки и поведенческие изменения, наблюдаемые в ответ на прием флоникамида, зависят от дозы и времени воздействия препарата.

Ключевые слова: флоникамид, летальная концентрация, Cyprinus carpio, симптомы интоксикации, поведение

\section{БЛАГОДАРНОСТИ}

Данное исследование было проведено при поддержке Центра международных научных исследований и сотрудничества (CISSC) Министерства науки, исследований и технологий Ирана.

\section{История статьи:}

Поступила в редакцию: 1 июля 2019 г. Принята к публикации: 1 августа 2019 г.

\section{Для цитирования:}

Ghelichpour M., Mirghaed A.T., Jimenez A.P. LC50 Determination and intoxication symptoms of a new pyridine carboxamide pesticide Flonicamid on common carp Cyprinus Carpio // Вестник Российского университета дружбы народов. Серия: Агрономия и животноводство. 2019. T. 14. № 3. С. 279-288. doi: 10.22363/2312-797X-2019-14-3-279-288

\section{Библиографический список}

1. Cho S.R., Koo H.N., Yoon C., Kim G.H. Sublethal effects of Flonicamid and thiamethoxam on green peach aphid, Myzus persicae and feeding behavior analysis // Journal of the Korean Society for Applied Biological Chemistry. 2011. Vol. 54. № 6. P. 889-898. doi: 10.1007/BF03253177

2. Morita M., Ueda T., Yoneda T., Koyanagi T., Haga T. Flonicamid, a novel insecticide with a rapid inhibitory effect on aphid feeding // Pest Management Science: formerly Pesticide Science. 2007. Vol. 63. № 10. P. 969-973. doi: 10.1002/ps.1423

3. Pazhanisamy K., Indra N. Toxic effects of arsenic on protein content in the fish, Labeo rohita (Hamilton) // Nature, Environment and Pollution Technology. Vol. 2007. Vol. 6. № 1. P. 113-116.

4. Mirghaed A.T., Ghelichpour M. Determination of lethal concentrations of indoxacarb in fingerling Cyprinus carpio at two temperatures // International journal of aquatic biology. 2015. Vol. 3. № 5. P. 339-345. doi: 10.22034/ijab.v3i5.113

5. Sandahl J.F., Baldwin D.H., Jenkins J.J., Scholz N.L. Comparative thresholds for acetylcholinesterase inhibition and behavioral impairment in coho salmon exposed to chlorpyrifos // Environmental Toxicology and Chemistry: An International Journal. 2005. Vol. 24. № 1. P. 136-145. doi: 10.1897/04-195R.1

6. Nwani C.D., Nagpure N.S., Kumar R., Kushwaha B., Kumar P., Lakra W.S. Lethal concentration and toxicity stress of Carbosulfan, Glyphosate and Atrazine to freshwater air breathing fish Channa punctatus (Bloch) // International Aquatic Research. 2010. № 2. P. 105-111.

7. Mohapatra B., Rengarajan K. Manual on bioassays in the laboratory and their techniques // CMFRI special publication. 1995. № 64. P. 1-75.

8. Jonsson C.M., Toledo M.C.F. Acute toxicity of endosulfan to the fish Hyphessobrycon bifasciatus and Brachydanio rerio // Archives of Environmental Contamination and Toxicology. 1993. Vol. 24. № 2. P. 151—155. doi: 10.1007/BF01141341

9. Joshi A., Rege M. Acute toxicity of some pesticides and a few inorganic salts to the mosquito fish Gambusia affinis (Baird \& Girard) // Indian Journal of Experimental Biology. 1980. Vol. 18. № 4. P. 435-437.

10. Naqvi S.M., Hawkins R. Toxicity of selected insecticides (Thiodan ${ }^{\circledR}$, Security ${ }^{\circledR}$, Spartan ${ }^{\circledR}$, and Sevin ${ }^{\circledR}$ ) to mosquitofish, Gambusia alfinis // Bulletin of Environmental Contamination and Toxicology. 1988. Vol. 40. № 5. P. 779—784. doi: 10.1007/BF01697530 
11. Swarup P.A., Rao D.M., Murty A. Toxicity of endosulfan to the freshwater fish Cirrhinus mrigala // Bulletin of Environmental Contamination and Toxicology. 1981. Vol. 27. № 1. P. 850-855. doi: 10.1007/BF01611106

12. Hussein S., El-Nasser M., Ahmed S. Comparative studies on the effects of herbicide atrazine on freshwater fish Oreochromis niloticus and Chrysichthyes auratus at Assiut, Egypt // Bulletin of Environmental Contamination and Toxicology. 1996. Vol. 57. № 3. P. 503-510. doi: $10.1007 / \mathrm{s} 001289900218$

13. Pandey S., Kumar R., Sharma S., Nagpure N., Srivastava S.K., Verma M. Acute toxicity bioassays of mercuric chloride and malathion on air-breathing fish Channa punctatus (Bloch) // Ecotoxicology and Environmental Safety. 2005. Vol. 61. № 1. P. 114-120. doi: 10.1016/j.ecoenv.2004.08.004

14. Chandra S. Toxic effect of Malathion on acetylcholinesterase activity of liver, brain and gills of freshwater catfish Heteropneutes fossilis // Environ. Conserv. 2008. № 9. P. 45-52.

15. Taheri Mirghaed A., Ghelichpour M., Mirzargar S.S., Joshaghani H., Ebrahimzadeh Mousavi $H$. Toxic effects of indoxacarb on gill and kidney histopathology and biochemical indicators in common carp (Cyprinus carpio) // Aquaculture Research. 2018. Vol. 49. № 4. P. 1616-1627. doi: 10.1111/are.13617

16. Roy W., Sutherland I., Rodger H., Varma K. Tolerance of Atlantic salmon, Salmo salar L., and rainbow trout, Oncorhynchus mykiss (Walbaum), to emamectin benzoate, a new orally administered treatment for sea lice // Aquaculture. 2000. Vol. 184. № 1-2. P. 19-29. doi: 10.1016/S0044-8486(99)00307-5

17. Nunes B., Gaio A., Carvalho F., Guilhermino L. Behaviour and biomarkers of oxidative stress in Gambusia holbrooki after acute exposure to widely used pharmaceuticals and a detergent // Ecotoxicology and Environmental Safety. 2008. Vol. 71. № 2. P. 341354. doi: 10.1016/j.ecoenv.2007.12.006

18. Backström T., Brännäs E., Nilsson J., Magnhagen C. Behaviour, physiology and carotenoid pigmentation in Arctic charr Salvelinus alpinus // Journal of Fish Biology. 2014. Vol. 84. № 1. P. 1-9. doi: 10.1111/jfb.12240

19. Sarikaya R., Yllmaz M. Investigation of acute toxicity and the effect of 2, 4-D (2, 4-dichlorophenoxyacetic acid) herbicide on the behavior of the common carp (Cyprinus carpio L., 1758; Pisces, Cyprinidae) // Chemosphere. 2003. Vol. 52. № 1. P. 195-201. doi: 10.1016/S0045-6535(03)00106-1

20. Farah M.A., Ateeq B., Ali M.N., Sabir R., Ahmad W. Studies on lethal concentrations and toxicity stress of some xenobiotics on aquatic organisms // Chemosphere. 2004. Vol. 55. № 2. P. 257-265. doi: 10.1016/j.chemosphere.2003.10.063

\section{Об авторах:}

Геличпур Мелика - кафедра здоровья водных животных, факультет ветеринарной медицины, Тегеранский университет, Иран, 14174, Тегеран, Енгхелаб пл., ул. Азар, 16; Центр международных научных исследований и сотрудничества (CISSC), Министерство науки, технологии исследований, Иран, 15875-7788, Тегеран; электронная почта: m.ghelichpour@ut.ac.ir; Scopus ID: 39961248800; ORCID: 0000-0002-8338-4235

Миргаед Али Тахери - кафедра здоровья водных животных, факультет ветеринарной медицины, Тегеранский университет, Иран, 14174, Тегеран, Енгхелаб пл., ул. Азар, 16; Центр международных научных исследований и сотрудничества (CISSC), Министерство науки, технологии исследований, Иран, 15875-7788, Тегеран; Scopus ID: 56158853500

Хименес Амалия Перес - факультет зоологии, Университет Гранады, кампус Фуэнтенуэва, Испания, 18071; Гранада, Ацера де Сан Илдефонсо; Междисциплинарный центр морских и экологических исследований (CIMAR), Университет Порту, Португалия, 4099-002; Порту; Scopus ID: 7202356622 